Paidéia, 2005, 15(31), 309-311

\section{RESENHA: A PSICANÁLISE NO DIVÃ ${ }^{1}$}

\author{
Menahem, Ruth (2001). Joyce Mc Dougall. \\ São Paulo: Via Lettera, 2001.
}

\section{Rodrigo Sanches Peres ${ }^{2}$ \\ FCL - Universidade Estadual Paulista de Assis}

Joyce McDougall se destaca como um dos principais expoentes da Psicanálise nos dias de hoje. Capaz de transitar por vertentes teóricas distintas, estabelece um diálogo tão audacioso quanto profícuo entre autores franceses e anglo-saxões e, como conseqüência, traz à luz contribuições de grande relevância para a clínica psicanalítica. Ressalte-se, porém, que McDougall concede total liberdade a seu pensamento, de maneira que não se furta ao direito de questionar as concepções clássicas sempre que considera necessário. Ademais, ele se preocupa em repensar suas próprias proposições teóricas quando se depara com os impasses inerentes ao trabalho terapêutico.

Evidencia-se, portanto, que o livro "Joyce McDougall”, escrito pela psicanalista francesa Ruth Menahem e lançado recentemente em território nacional, apresenta-se de antemão como uma obra interessante. Publicado originalmente em 1999 pela Presses Universitaires de France, o texto de Menahem foi traduzido para a língua portuguesa por Mônica Seincman e apresentado aos leitores brasileiros pela Editora Via Lettera como um dos volumes da coleção "Psicanalistas de Hoje”, que traz também títulos dedicados a André Green e Melanie Klein, dentre outros renomados autores contemporâneos.

Menahem inicialmente delineia uma síntese da biografia de McDougall e demonstra que sua vida e sua obra são, de fato, indissociáveis. O primeiro capítulo do livro trata de sua infância na Nova Zelândia e do relacionamento conflituoso com a avó paterna que despertou precocemente seu interesse pelos meandros do funcionamento psíquico. Sua paixão juvenil pelo teatro recebe atenção especial, uma vez que a aproximou de Jimmy, o educador que viria a ser seu

\footnotetext{
${ }^{1}$ Recebido para publicação em 02/08/2005 e aceito em 16/09/2005. 2 Rodrigo Sanches Peres: FCL - Universidade Estadual Paulista, Endereço para correspondência: Rua Padre Feijó, 754 - Ribeirão Preto - SP, CEP: 14050-360; E-mail: rodrigosanchesperes@yahoo.com.br
}

primeiro marido. Além disso, Menahem aborda um assunto delicado: o rancor que McDougall desenvolveu na idade adulta por sua mãe, a quem atribuiu a responsabilidade pela eclosão do linfosarcoma que matou seu pai.

É preciso salientar que o primeiro capítulo do livro ainda apresenta um valioso panorama do percurso profissional de McDougall. Torna-se patente, assim, que seu fascínio pela psicanálise é anterior a sua opção pelo curso de graduação em Psicologia e a levou a preterir, à revelia de sua família, a carreira médica. Evidencia-se também que sua formação psicanalítica - iniciada em Londres com Anna Freud e concluída em Paris com Serge Lebovici - foi marcada essencialmente pela renúncia à visão dogmática que caracterizava o pensamento de alguns de seus contemporâneos.

O segundo capítulo do livro tem como objeto a obra de McDougall e é dividido em três partes. Na primeira delas - dedicada às complexas relações que fazem da mente e do corpo um todo indissociável Menahem considerou relevante negligenciar a apresentação de casos clínicos e privilegiar a definição de alguns dos mais importantes conceitos forjados por McDougall, tais como "ato-sintoma", "histeria arcaica” e "psicose atual”. Para tanto, a metáfora teatral - que ocupa um lugar de destaque em toda a sua obra - é utilizada como eixo norteador de uma discussão teórica bem articulada. Desse modo, o leitor pode compreender que McDougall reformula a concepção psicanalítica tradicional ao propor que, em contraste com o que defendia Freud, não apenas na histeria, mas sim em todas as estruturas de personalidade, o trabalho clínico envolve a reconstrução de um drama particular que tem como palco o corpo ora meramente biológico e ora potencialmente representável - do sujeito. Com efeito, Menahem ressalta que essa reconstrução depende, para McDougall, da capacidade do indivíduo aceitar a existência do inconsciente e de tolerar as frustrações inerentes ao processo terapêutico.

Na segunda parte do segundo capítulo, Menahem trata da sexualidade humana na concepção de McDougall, que tem como base dois pressupostos teóricos clássicos, a saber: a bissexualidade psíquica infantil e a fantasia da cena primitiva. Não obstante, Menahem enfatiza que McDougall inova ao 


\section{Rodrigo Sanches Peres}

propor que o desenvolvimento da feminilidade é mais complexo do que a evolução da masculinidade, já que depende, a seu ver, não apenas da superação do conflito edípico, mas, sobretudo, da estabilização do narcisismo, da intensificação do prazer erótico e da utilização criativa das identificações homossexuais.

McDougall também ousa ao introduzir o termo "neo-sexualidades" na literatura psicanalítica para fazer referência às orientações sexuais desviantes. Menahem, por sua vez, tem o mérito de esclarecer que o termo em questão não possui, ao contrário do que se poderia pensar a princípio, qualquer conotação moral, visto que designa as soluções ilusórias homossexuais ou heterossexuais criadas pelo indivíduo para superar conflitos decorrentes da ambivalência parental em relação à masculinidade e à feminilidade. Além disso, reforça que tais soluções - sobretudo na perversão - são importantes para a manutenção da identidade do sujeito. Ainda na segunda parte do segundo capítulo, Menahem aponta que, de acordo com McDougall, muitas vezes a sexualidade é utilizada como uma droga na tentativa de eliminar angústias primitivas associadas ao temor da fragmentação do próprio ego. Esse quadro patológico pode ser observado, como bem assinala Menahem, principalmente em sujeitos que, em virtude de excessos ou carências parentais no exercício da função de paraexcitação, não possuem uma representação interna adequada da instância materna e, como conseqüência, buscam compulsivamente no mundo externo um objeto capaz de substituí-la.

A terceira parte do segundo capítulo focaliza o olhar crítico que McDougall lança sobre a prática clínica e seus objetivos. A propósito, essa capacidade de colocar a psicanálise em seu próprio divã pode ser considerada o grande diferencial da autora em questão. Menahem destaca que, para McDougall, a adaptação à norma não deve ser entendida como o objetivo do trabalho terapêutico, pois, quando isso ocorre, as idiossincrasias que conferem riqueza à existência humana tendem a ser malogradas. Seguindo esse raciocínio, é possível propor que os psicanalistas devem se preocupar em conferir um certo caráter subversivo às suas práticas.

Menahem conclui o segundo capítulo definindo outros dois conceitos de grande relevância na obra de McDougall, a saber: "normopatia” e "desafetação". Ambos foram cunhados a partir da descrição de distúrbios da economia afetiva - decorrentes, na maioria dos casos, de desarmonias no vínculo com a figura materna - que fomentam a exclusão de representações associadas a sentimentos e emoções do aparelho psíquico. No entanto, é preciso salientar que esses distúrbios não provocam restituições psicóticas, tais como delírios e alucinações. Em contrapartida, engendram uma cisão entre a mente e o corpo e favorecem a eclosão de doenças orgânicas. Em função disso, Menahem afirma que McDougall amplia a metapsicologia, pois defende que o afeto pode ser sumariamente eliminado do ego, e não apenas convertido, deslocado ou transformado, como Freud propôs que ocorre, respectivamente, na histeria de conversão, na neurose obsessiva e na neurose de angústia ou na melancolia. Menahem também esclarece que essa operação psíquica leva o indivíduo a agir como se nunca tivesse tido acesso aos conteúdos afetivos repudiados, privando-o do acesso a grande parte de sua própria realidade interna e impedindo-o de entrar em contato com todas as nuances emocionais de suas experiências.

No terceiro capítulo, Menahem compila uma proveitosa bibliografia de McDougall. Ressalte-se, todavia, que a publicação mais recente citada data de 1998, o que aponta a necessidade de uma rigorosa atualização. Além disso, a bibliografia deveria ser seguida de indicações para que pudesse ser utilizada como ponto de partida para o leitor interessado em se aprofundar no estudo da obra da autora em questão. Por fim, cumpre assinalar que textos de comentadores de McDougall - tais como os psicanalistas brasileiros Plínio Montagna e Paulo Roberto Ceccarelli poderiam ser incluídos nesta seção do livro com o intuito de torná-la mais completa.

Já no quarto e último capítulo, o leitor tem a oportunidade de estabelecer um contato inicial com os escritos de McDougall, uma vez que Menahem apresenta trechos de alguns de seus textos. A maioria deles, contudo, já foi publicada em língua portuguesa. Evidencia-se, dessa maneira, que Mônica Seincman, responsável pela tradução de Menahem, perdeu a chance de incluir neste capítulo algumas das diversas publicações de McDougall que não se encontram disponíveis no país. Faz-se necessário mencionar ainda que os recortes executados por Menahem 
nos textos de McDougall são pouco criteriosos e, em muitas situações, comprometem sua efetiva compreensão.

É importante salientar, contudo, que os acertos de Menahem são mais significativos do que os deslizes. Seu livro, portanto, se destaca como uma leitura obrigatória não apenas para os estudiosos da biografia e do pensamento de McDougall, mas também para os adeptos da psicanálise que se preocupam em acompanhar os avanços pós-freudianos. Assim sendo, pode auxiliar a difundir as idéias e os ideais de uma autora que infelizmente ainda não alcançou a devida notoriedade no país. Ademais, ilustra que, como sutilmente exemplifica McDougall, a equilibrada combinação de talento, sensibilidade e ousadia é capaz de criar novos paradigmas para a teoria e a clínica psicanalítica. 